\title{
Infecções Hospitalares em 46 Pacientes Submetidos a Artro- plastia Total do Quadril
}

\author{
Hospital Infections in 46 Patients Submitted to Total Hip Replacement
}

Ana Lúcia Lei Munhoz lima; Antonio Alci Barone

\section{RESUMO}

Foram estudados 46 pacientes submetidos a artroplastia total do quadril em um Instituto de Ortopedia de São Paulo, Brasil, no período de 1993 a 1995, com o objetivo de obter a real frequência das infecções hospitalares da ferida operatória superficial e profunda que ocorrem nessa cirurgia. O estudo baseou-se no acompanhamento pré-operatório, trans-operatório e pós-operatório com seguimento mínimo de três meses de todos os pacientes, no sentido de caracterizar os agentes etiológicos das infecções e os fatores de risco que contribuem para o seu desenvolvimento. Foi observada uma freqüência total de $15.1 \%$ de infecções hospitalares, sendo 6.5\% de infecção superficial da ferida operatória, 6.5\% de infecção profunda e $2.1 \%$ de infecção do trato urinário. Os agentes etiológicos encontrados foram Pseudomonas aeruginosa (2 casos), Staphylococcus coagulase negativo (2 casos), Morganella morgani (1 caso) e associação de Acinetobacter calcoaceticus (2 casos). O fator de risco com significância estatística observado nesta casuística foi o tempo cirúrgico aumentado.

Concluiu-se que a frequência de infecção da ferida cirúrgica superficial e profunda nas artroplastias totais de quadril foi maior, nesta casuística, do que a relatada na literatura internacional, com elevada participação de bacilos Gram-negativos como agentes etiológicos e tendo como principal fator de risco o tempo cirúrgico aumentado.

\section{SUMMARY}

We studied 46 patients submitted to total hip replacement at an Orthopaedics Institute in the city of São Paulo, Brazil, from 1993 to 1995, in order to determine the real frequency of hospital infections of the superficial and deep surgical wounds occurring in this operation. The study consisted of preoperative, transoperative and postoperative monitoring and a minimum follow-up period of three months for all patients in order to characterise the etiologic agents of the infections and risk factors contributing to the development of the latter.

The total frequency of hospital infections was $15.1 \%, 6.5 \%$ of them being superficial wound sepsis, 6.5\% deep wound sepsis and $2.2 \%$ infection of the urinary tract. The etiologic agents detected were: Pseudomonas aeruginosa (2 cases), coagulasenegative Staphylococcus (2 cases), Morganella morgani (1 case), and association of Acinetobacter calcoaceticus (2 cases). The risk factor showing a statistically significant effect in this patient series was increased surgical time.

We conclude that the frequency of superficial and deep surgical wound sepsis in total hip replacement surgeries was higher in the present series compared to data reported in the international literature, with a high participation of Gram-negative bacilli as etiologic agents and with increased surgical time representing the major risk factor.

Trabalho realizado no Grupo de Infecção do Instituto de Ortopedia e Traumatologia e no Departamento de Doenças Infecciosas e Parasitárias do Hospital das Clínicas da Faculdade de Medicina da Universidade de São Paulo. 


\section{INTRODUÇÃO}

O desenvolvimento das prótese articulares representa um grande avanço na tecnologia biomédica. O implante de próteses, principalmente quadril e joelho, vem se tornando cada vez mais frequente, estimando-se que 150 mil novas próteses de quadril são realizadas por ano nos Estados Unidos e 400 mil em todo o mundo. Quando implantadas, propiciam significante redução no desconforto dos pacientes acometidos de doenças da articulação coxo-femural e imensurável melhora de sua mobilidade, especialmente quando não complicadas por processos infecciosos.

Os dados obtidos da literatura internacional revelam que 1 a $5 \%$ das próteses do quadril tornam-se infectadas; embora menos frequente do que as perdas mecânicas do implante, a infecção é considerada a mais devastadora das complicações, pois acarreta morbidade por internações prolongadas, intervenções cirúrgicas repetidas, podendo culminar na perda definitiva do implante com encurtamento do membro afetado, deformidades graves e perenes, bem como levar ao óbito em infecções fulminantes. Além disso, todos os procedimentos envolvidos na tentativa de resolução da infecção envolvem custo elevado, estimado em 40 a 80 milhões de dolares/ano nos Estados Unidos.

Com a ampliação das indicações para o uso de próteses articulares, aperfeiçoamento das técnicas cirúrgicas empregadas por grupos especializados e desenvolvimento de novos modelos protéticos, aumenta a necessidade de conhecimento mais profundo das infecções associadas a esses procedimentos.

Já se conhece que o aparecimento de infecções nas artroplastias pode estar relacionado com eventos presentes antes, durante a após a cirurgia. O objetivo deste trabalho foi estabelecer a frequência das infecções hospitalares nas artroplastias totais do quadril, bem como os fatores de risco para o seu desenvolvimento. Definimos infecções hospitalarse como todas aquelas que ocorrem até o trigésimo dia pós-operatório. Entretanto, deve-se levar em consideração que, em implantes protéticos, as infecções que se desenvolvem na região operada até um ano após a cirurgia podem estar relacionadas com a mesma.

Todos os 46 pacientes foram operados eletivamente pelo grupo de quadril do Instituto de Ortopedia e Traumatologia do Hospital das Clínicas da Faculdade de Medicina da Universidade de São Paulo, na tentativa de uniformizar as condutas e restringir variáveis. A escolha eletiva dos pacientes permitiu-nos proceder uma avaliação pré-operatória cuidadosa na busca e tratamento de focos infecciosos pulmonares, dentários, cutâneos e urinários, bastante implicados na disseminação hematogênica de bactérias e contaminação da prótese no pós-operatório.

\section{INTRODUCTION}

The development of joint prostheses represents a great advancement in biomedical technology. The implantation of prostheses, especially of the hip and knee, is becoming increasingly frequent, with an estimated 150 thousand hip arthroplasties being performed per year in the United States and 400 thousand in the whole world. When implanted, these prostheses provide a significant reduction in the discomfort of patients with coxofemoral joint diseases and an immeasurable improvement in mobility, especially when not complicated by infectious processes.

Literature data reveal that 1 to $5 \%$ of hip prostheses become infected. Although less frequent than mechanical loss of the implant, infection is considered to be the most devastating complication since it involves prolonged hospitalisation and repeated surgical interventions possibly culminating in the definitive loss of the implant, with shortening of the limb involved, severe and permanent deformities, and even death in cases of fulminating infection. Furthermore, all the procedures involved in the attempts to resolve the infection are very expensive, with their cost being estimated at 40 to 80 million dollars/year in the United States.

With the increasing indications of the use of joint prostheses, the improvement of surgical techniques employed by specialised groups and the development of new implant models, there is an increasing necessity for more in-depth knowledge of the infections associated with these procedures.

The onset of sepsis in arthroplasty is known to be related to events occurring before, during and after surgery. The objective of the present study was to determine the frequency of hospital infections occurring in total hip arthroplasty, as well as the risk factors for their development. We defined as hospital infections all of those that occurred up to the thirtieth postoperative day. However, it should be kept in mind that the infections that develop in the operated region up to one year after surgery for prosthesis implantation may be related to the surgery itself.

All 46 patients were submitted to elective surgery, and were operated upon by the hip group of the Institute of Orthopaedics and Traumatology of the University Hospital, Faculty of Medicine, University of São Paulo, in an attempt to obtain uniform procedures and to limit the variables. Elective selection of the patients permitted us to perform a careful preoperative evaluation in which we searched for and treated pulmonary, dental, skin and urinary foci of infection, which are considerably implicated in the postoperative hematogenic dissemination of bacteria and contamination of the prosthesis. 


\section{CASUÍSTICA E MÉTODOS}

Durante o período de 1993 a 1995, foram acompanhados 46 pacientes, cuja mediana de idade foi de 54 anos (variando de 22 a 80 anos), sendo 21 do sexo masculino (45.7\%) e 25 do sexo feminino (54.3\%).

Avaliação pré-operatória: foram obtidos dados epidemiológicos relativos a idade, sexo, condições pré-existentes, doença que gerou a indicação da artroplastia, cirurgias anteriores ortopédicas ou não, história pregressa de infecção ósteo-articular ou de outras localizações, medicações em uso, tabagismo, etilismo e uso de drogas ilícitas injetáveis.

Os dados clínicos resultaram de exame físico geral e específico.

Exames laboratoriais constaram de hemograma, velocidade de hemossedimentação, glicemia de jejum, dosagem sérica de uréia e creatinina, coagulograma, cultura de urina e de secreção nasofaríngea com antibiograma se crescimento bacteriano. Nos pacientes com antecedente de infecção ósteo-articular no local a ser operado, foi realizada Cintilografia Óssea com imuneglobulina marcada com Tecnécio.

As alterações detectadas, assim como eventuais focos infecciosos foram tratados e resolvidos antes da liberação para a cirurgia.

Avaliação trans-operatória: todos os pacientes foram internados no dia da cirurgia. Foram operados no Centro Cirúrgico do Instituto de Ortopedia e Traumatologia, onde as normas de esterilização dos materiais, desinfecção das salas, acondicionamento das próteses e verificação de suas condições de esterilização seguem padronização da Comissão de Controle de Infecção Hospitalar da instituição.

A técnica cirúrgica utilizada foi a padronizada pelo grupo de quadril do IOT, em todos os casos. O número de médicos que participou do campo cirúrgico foi anotado. Foi observado o uso ou não de cimento para a fixação das próteses.

Todos os pacientes receberam antibioticoprofilaxia com Cefalotina, dois gramas por via endovenosa na indução anestésica e, a seguir, um grama a cada seis horas por 48 horas.

Durante o ato cirúrgico foram colhidos fragmentos ósseos para cultura e antibiograma e para exame histopatológico.

Avaliação pós-operatória: todos os pacientes foram avaliados diariamente até a alta hospitalar, no trigésimo dia de pós-operatório e, no mínimo, três meses após.

As infecções foram diagnosticadas com base nos critérios do Center for Diseases Control (NNISS) de 1988.

\section{RESULTADOS}

Pré-operatório: as condições pré-existentes foram 39.1\% sem qualquer doença relevante, $15.2 \%$ portadores de artrite reumatóide, $10.8 \%$ com hipertensão arterial sistêmica, 8,6\% recebendo corticoterapia, $4.3 \%$ com diabetes mellitus, $13 \%$ com história pregressa de cirurgia local.

\section{CASES AND METHODS}

A total of 46 patients were followed up from 1993 to 1995. Median patient age was 54 years(range: 22 to 80 years), 21 were males (45.7\%) and 25 females (54.3\%).

Preoperative evaluation: epidemiological data concerning age, sex, preexisting conditions, disease that led to the indication of arthroplasty, previous surgeries (orthopaedic or not), previous history of osteoarticular infection or infections localized elsewhere, medications being taken, smoking habit, alcohol use and abuse of injectable illicit drugs were obtained.

Clinical data were obtained by general and specific physical examination.

Laboratory tests included blood counts, blood sedimentation rate, fasting blood glucose levels, determination of serum urea and creatinine, coagulogram, urine culture and culture of nasopharyngeal secretion, with an antibiogram when bacterial growth was detected. Patients with a history of osteoarticular infection at the site to be operated upon were submitted to bone scintigraphy with technetiumlabelled immunoglobulin.

The alteration detected, as well as eventual focal points of infection were treated and resolved before surgery.

Transoperative evaluation: all patients were admitted to hospital on the day of surgery. They were operated upon at the Surgical Center of the Institute of Orthopaedics and Traumatology (IOT), where the regulations for material sterilisation, room disinfection, prosthesis packing and verification of its sterilisation conditions follow the standards established by the Committee of Control of Hospital Infection of the institution. The surgical technique used in all cases was that standardised by the hip group of the IOT. The number of physicians who participated in the surgery was recorded. We also recorded whether or not cement was used for prosthesis fixation.

All patients received prophylactic antibiotic treatment with cephalothin, 2 grams intravenously during induction of anaesthesia, followed by one gram every six hours for 48 hours. Bone fragments were collected during the surgical act for culture and antibiogram and for histopathological examination.

Postoperative evaluation: all patients were assessed daily until discharge and then on the thirtieth postoperative day and at least three months later. The infections were diagnosed based on the 1988 criteria of the Center for Diseases Control (NNISS).

\section{RESULTS}

Preoperative examination: $39.1 \%$ of the patients showed no relevant disease, $15.2 \%$ had rheumatoid arthritis, $10.8 \%$ had systemic arterial hypertension, $8.6 \%$ were under corticoid treatment, $4.3 \%$ had diabetes mellitus, and $13 \%$ had a previous history of local surgery.

The diseases that led to the indication of arthroplasty were hip osteoarthrosis in 50\% of cases, rheumatoid arthritis in 13\%, aseptic necrosis of the femoral head in $15.2 \%$, ankylosing spondylitis in $10.8 \%$, sequelae of fracture of the femur in $4.3 \%$, sequelae of hip pyoarthritis in $2.1 \%$, epiphysiolisthesis in $2.1 \%$, and bilateral Otto 
As doenças que geraram a indicação da artroplastia foram em $50 \%$ dos casos, osteartrose do quadril, $13 \%$ artrite reumatóide, 15.2\% necrose asséptica da cabeça do fêmur, 10.8\% espondilite anquilosante, $4.3 \%$ sequela de fratura do fêmur, $2.1 \%$ sequela de pioartrite do quadril, $2.1 \%$ epifisiolistese e $2.1 \%$ ottopelvis bilateral.

Os exames inespecíficos mostraram 63\% com velocidade de hemossedimentação aumentada (>20 mm), 19.5\% (9 pacientes) com urocultura positiva com mais de 100 mil Unidades Formadoras de Colônia de uma mesma bactéria, a saber Escherichia coli - 5 casos, Enterobacter cloacae, Enterobacter agglomerans, Providencia rettgeri e Candida sp, um caso de cada. Quatro pacientes (8.6\%) apresentaram cultura de nasofaringe positiva para Staphylococcus aureus.

Trans-operatório: a equipe cirúrgica variou de três a sete médicos, sendo que o tempo de cirurgia oscilou de 30 a 300 minutos, com média de 150 minutos. 54.3\% das próteses foram fixadas com cimento; $45.7 \%$, sem cimento.

Em dois pacientes, houve crescimento de Staphylococcus coagulase negativo nos fragmentos ósseos colhidos durante a cirurgia. Entretanto, em nenhum fragmento ósseo, o exame histopatológico revelou qualquer sinal de processo infeccioso.

Pós-operatório: o tempo de internação variou de seis a 36 dias.

Infecção da ferida cirúrgica foi detectada em 6 pacientes (15.1\%), três com infecção superficial e três com infecção profunda; um destes pacientes apresentou infecção urinária concomitante. Os agentes etiológicos isolados desses locais estão na Tabela 1.

\section{TABELA 1 - Bactérias isoladas da ferida cirúrgica em 6 pacientes operados de artroplastia total do quadril}

\begin{tabular}{|c|c|c|}
$\begin{array}{c}\text { Paciente } \\
\text { número }\end{array}$ & Local da infecção & \multicolumn{1}{c|}{ Agente(s) isolado(s) } \\
\hline 6 & superficial & Pseudomonas aeruginosa \\
\hline 10 & profunda & Pseudomonas aenginosa \\
\hline 22 & profunda & Staphylococcus coagulase negativo \\
\hline 24 & scinetobacter calcoaceticus \\
\hline 28 & superficial & Staphylococcus coagulase negativo \\
\hline 33 & profunda & Não identificado \\
\hline
\end{tabular}

\section{DISCUSSÃO}

Embora os resultados atuais sejam melhores do que seria possível imaginar nos primeiros anos após a introdução de artroplastias totais de quadril ou joelho, o manuseio de infecções estabelecidas em articulações protéticas continua difícil e dispendioso em termos de tempo e recursos. Portanto, é importante a cuidadosa atenção na prevenção da infecção, mas as incertezas e as dificuldades continuam (1). Embora as possibilidades diagnósticas tenham melhorado com a evolução das novas técnicas imunológicas e de imagem, as consequências devastadoras de uma infecção, mesmo com diagnóstico precoce, ainda não podem ser abortadas. Em consequência, investigações mais profundas e o desenvolvimento de técnicas adicionais devem ser imaginadas ${ }^{(2)}$. A despeito das dramáticas quedas nos índices pelvis in $2.1 \%$

Nonspecific tests showed that $63 \%$ of the patients had an increased blood sedimentation rate (>20 mm), and 19.5\% (9 patients) had a positive urine culture with more than 100 thousand colony forming units of the same bacterium, i.e. Escherichia coli in 5 cases, and Enterobacter cloacae, Enterobacter agglomerans, Providencia rettgeri and Candida sp in one patient each. Four patients (8.6\%) had a Staphylococcus aureus-positive nasopharyngeal culture.

Transoperative evaluation: the surgical team ranged from three to seven doctors and surgical time ranged from 30 to 300 minutes, with a mean of 150 minutes; $54.3 \%$ of the prostheses were fixed with cement and $45.7 \%$ without cement.

In two patients there was growth of coagulase-negative Staphylococcus in the bone fragments collected during surgery. However, no signs of infectious processes were detected in any bone fragment by histopathological examination.

Postoperative evaluation: hospitalisation time ranged from six to 36 days. Surgical wound sepsis was detected in 6 patients (15.1\%), three of them with superficial infection and three with deep infection. One of these patients had a concomitant urinary infection. The etiologic agents isolated from these sites are listed in Table I.

\section{Table I - Bacteria isolated from the surgical wound of six patients submitted to total hip arthroplasty}

\begin{tabular}{|c|c|c|}
$\begin{array}{c}\text { Patient } \\
\text { no. }\end{array}$ & Site of infection & \multicolumn{1}{|c|}{ Agent(s) isolated } \\
\hline 6 & superficial & Pseudomonas aeruginosa \\
\hline 10 & deep & Pseudomonas aeruginosa \\
\hline 22 & deep & Coagulase-negative Staphylococcus and \\
\hline 24 & scinetobacter calcoaceticus \\
\hline 28 & superficial & Coagulase-negative Staphylococcus \\
\hline 33 & deep & Unidentified \\
\hline
\end{tabular}

\section{DISCUSSION}

Athough the present results are better than those that could be imagined during the first years after the introduction of total hip or knee arthroplasties, the management of infections established in prosthetic joints continues to be difficult and expensive in terms of

time and resources. Thus, even though the uncertainties and difficulties continue, careful measures should be taken to prevent infection. ${ }^{1}$ Despite the great improvement of diagnostic possibilities with the evolution of new immunological and imaging techniques, the devastating consequences of an infection, even after an early diagnosis, cannot be avoided as yet. For this reason, more in-depth investigations and the development of additional techniques are required. ${ }^{2}$ Although there was a dramatic reduction in the rates of infection due to intraoperative contamination, the rates of late infection continue to be essentially the same. At present, the rate of infection throughout the useful life of the prosthesis continues to be approximately $1 \%{ }^{3}$

A survey of the literature reveals the concern with the assessment of local or distant infectious foci when joint prostheses are implanted. There are countless reports of hematogenic dissemination of these 
de infecção decorrente de contaminação intra-operatória, os índices de infecção tardia continuam essencialmente os mesmos. Atualmente, as taxas de infecção durante toda a vida da prótese permanmecem aproximadamente em 1\% (3).

Em todas as citações bibliográficas que revisamos, nota-se a preocupação com a avaliação de focos infecciosos locais ou à distância quando da implantação de próteses articulares. São inúmeros os relatos de disseminação hematogênica de tais focos após a implantação das próteses, como observamos em relação a focos urinários, de úlceras de membros inferiores, pneumonias e abscesos cutâneos, dentre outros ${ }^{(4,5)}$.

Alguns resultados encontrados na casuística avaliada no presente trabalho foram extremamente relevantes em relação à avaliação pré-operatória. Foram detectadas infecções urinárias assintomáticas no pré-operatório em 19.5\% dos pacientes (8 mulheres e 1 homem),ocorrendo na faixa etária média de 56.3 anos. Esta prevalência é bem maior do que aquela encontrada na população geral da mesma faixa etária, segundo relatos de ${ }^{(6)}$, em 1984, que encontrou $4.4 \%$ das mulheres e $0.5 \%$ dos homens com infecção urinária.

Levando-se em conta que todos os pacientes eram assintomáticos, que a prevalência foi maior do que na população geral e que há possibilidade de disseminação hematogênica destes microrganismos, a urocultura torna-se um exame obrigatório no pré-operatório das artroplastias do quadril e não somente quando existirem sintomas, como preconizado por CHARNLEY e EFTHEKAR ${ }^{(7)}$.

Ainda no pré-operatório, encontramos $8.6 \%$ de portadores nasais de Staphylococcus aureus, prevalência similar à descrita por HILL et al(8). Apesar de não ser clara a correlação do estado de portador sem doença cutânea com a disseminação hematogênica(8), os pacientes foram submetidos à descolonização com Mupirocin a 2\% nasal no pré-operatório

Não houve correlação estatística entre as infecções urinárias e os portadores nasais de estafilococo com o desenvolvimento de infecções pós-operatórias.

No período trans-operatório, foram relevantes os achados em relação ao tempo cirúrgico. Assim como citado por FITZGERALD et $a^{(2)}$, os casos que evoluíram com infecção pós-operatória tiveram tempo cirúrgico maior do que 140 minutos.

A frequência da infecção da ferida operatória, superficial e profunda, na alta dos pacientes, foi de $8.6 \%$ e na reavaliação do trigésimo dia elevou-se para 13\%. Estes dados estão em concordância com CARDO et al(9) e TAYLOR et al(10) que observaram incremento em torno de $20 \%$ no diagnóstico de infecções da ferida operatória quando realizada reavaliação após a alta hospitalar. Em estudo específico de infecções da ferida operatória em atroplastias de quadril e joelho, TAYLOR et al ${ }^{(10)}$, concluíram que $77 \%$ destas foram diagnosticadas após a alta hospitalar. Estes achados mostram a importância da vigilância das feridas operatórias após a lata hospitalar, não só para detectarmos a real frequência das mesmas, mas também para o diagnóstico precoce e o tratamento adequado, evitando-se assim as infecções profundas das artroplastias que se originam em infecções superficiais foci after prosthesis implantation, as observed for urinary foci, lower limb ulcers, pneumonia and skin abscesses, among others. ${ }^{4,5}$

Some of the results obtained with the present series showed the extreme relevance of preoperative evaluation. Asymptomatic urinary infections were detected preoperatively in $19.5 \%$ of patients (8 women and 1 man), occurring on average at 56.3 years of age, This prevalence is much higher than that observed in the general population of the same age range, as reported by Glynn and Sheehan, ${ }^{6}$ who found urinary infection in $4.4 \%$ of the women and $0.5 \%$ of the men.

Considering that all patients were asymptomatic, that the prevalence was higher than in the population at large, and that the possibility of hematogenic dissemination of these microorganisms exists, urine culture becomes an obligatory preoperative exam for hip arthroplasty in all cases and not only in symptomatic cases, as recommended by Charnley and Efthekar. Also preoperatively, we found $8.6 \%$ of patients with nasal Staphylooccus aureus, a prevalence similar to that reported by Hill et al. ${ }^{8}$ Although the correlation between carrier status without skin sisease and hematogenuc dissemination, ${ }^{8}$ these patients were treated with $2 \%$ mupyrocin before surgery.

There was no significant correlation between urinary infection or nasal presence of staphyococcus and development of postoperative infections.

During the transoperative period we obtained relevant results in terms of surgical time. As also reported by Fitzgerald et al., ${ }^{2}$ patients who developed postoperative infection were those submitted to a surgical time of more than 140 minutes.

The frequency of superficial and deep surgical wound infections was $8.6 \%$ at discharge and increased to $13 \%$ on the occasion of reevaluation on the thirtieth day. These data agree with those reported by Cardo et al..$^{9}$ and Taylor et al..$^{10}$ who observed an increase of about $20 \%$ in the diagnosis of surgical wound infections in patients reevaluated after discharge from hospital. In a specific study of surgical wound infections in arthroplasties of the hip and joint, Taylor et al. ${ }^{10}$ concluded that $77 \%$ of them were diagnosed after discharge from hospital. These findings show the importance of monitoring the surgical wounds after discharge, not only in order to detect their real frequency but also for early diagnosis and proper treatment, thus preventing the occurrence of deep sepsis originating from superficial sepsis with a delayed diagnosis.

We should also point out the high occurrence of Gram-negative bacilli as etiologic agents of superficial and deep post-arthroplasty infections, in contrast to the staphylococcal infections traditionally reported in the world literature.

\section{CONCLUSIONS}

The frequency of superficial and deep surgical wound infections in total hip arthroplasty was higher in the present series than the values reported in the literature.

Surgical time was the most relevant risk factors for the development of postoperative infections.

The occurrence of Gram-negative bacilli as etiologic agents of these infections was higher than the rate commonly reported in the literature for this type of surgery. 
diagnosticadas tardiamente.

Ainda vale ressaltar a elevada ocorrência de bacilos Gramnegativos como agentes etiológicos de infecções superficiais e profundas pós artroplastias, ao contrário das infecções estafilocócicas tradicionalmente descritas na literatura mundial.

\section{CONCLUSÕES}

A frequência de infecções da ferida operatória superficial e profunda nas artroplastias totais do quadril foi maior na casuística estudada do que as citadas na literatura mundial.

O tempo cirúrgico foi o fator de risco de maior relevância para o desenvolvimento das infecções pós-operatórias.

A ocorrência de bacilos Gram-negativos como agentes etiológicos dessas infecções foi maior do que a habitualmente citada nas publicações sobre infecções pós-artroplastias do quadril.

\section{REFERÊNCIAS}

1. Gillespie WJ. Prevention and management of infection atter total joint replacement. Clin Infect Dis 1997; 25: 1310-1317.

2. Fitzgeral Jr RH, Nolan DR, Ilstrup DM, Vanscpy RE, Washington JA Coventry MB. Deep wound sepsis following total hip arthroplasty. J Bone Joint Surg 1977; 59a: 847-855.

3. Nasser S. Prevention and tratment of sepsis in total hip replacement surgery. Orthop Clin North Am 1992; 23: 265-277.

4. D'Ambrosia RD, Shoji $H$ and Heater R. Secondarily infected total joint replacements by hematogenous spread. J. Bone Joint Surg. 1976; 58-a(4): 450-453

5. Donovan TL, Gordon RO and Nagel DA. Urinary infections in total hip arthroplasty. J. Bone Joint Surg. 1976; 58-a(8): 1134-1137.

6. Glynn MK, Sheehan JM. The significance of asymptomatic bacteria in patients undergoing hip/Knee arthroplasty. Clin Orthop. 1984; 185: 151-154.

7. Charnley $\mathrm{J}$ and Eftekhar N. Postoperative infection in total prosthetic replacement arthroplasty of the hip-joint. B. J. Surg. 1969; 56(9): 641-649.

8. Hill, J.; Howell, A.; Blower, S.R. Effect of clothing on dispersal of Staphylococcus aureus by males and females Lancet 1974; II: 1131 1133

9. Cardo DM, Falk PS, Mayhall CG. Validation of Surgical Wound Surveillance. Infect. Control Hosp. Epidemiol. 1993; 14 (4): 211-215.

10.Taylor S, Pearce P, McKenzie M, Taylor GD. Wound infection in Total Joint Arthroplasty: Effect of Extended Wound Surveillance on Wound Infection Rates. Canadian Journal of Surgery. 1994; 37: 217-220. 